\title{
Comparison of the first Iranian native Ornithobacterium rhinotracheale vaccine with conventional vaccine: A challenge study
}

\author{
N. Ghasemipour ${ }^{1}$, H. Goudarzi ${ }^{2}$, M. Banani² and K. Asasi ${ }^{1}$
}

1. Department of Clinical Sciences, Poultry Diseases Research Center, Veterinary School of Shiraz University, Shiraz, Iran; 2. Department of Avian Diseases Research and Diagnosis, Razi Vaccine and Serum Research Institute, Agricultural Research, Education and Extension Organization, Karaj, Iran.

Corresponding author: K. Asasi, e-mail: asasi@Shirazu.ac.ir

Co-authors: NG: naghasemipour48@gmail.com, HG: h.goudarzi46@gmail.com, MB: mbanani111@gmail.com Received: 10-11-2019, Accepted: 10-02-2020, Published online: 12-04-2020

doi: www.doi.org/10.14202/vetworld.2020.655-660 How to cite this article: Ghasemipour N, Goudarzi H, Banani M, Asasi K (2020) Comparison of the first Iranian native Ornithobacterium rhinotracheale vaccine with conventional vaccine: A challenge study, Veterinary World, 13(4): 655-660.

\begin{abstract}
Background and Aim: The best strategy to prevent or control an Ornithobacterium rhinotracheale (ORT) infection is vaccination. The present study aimed to compare the efficacy of the first Iranian inactivated ORT vaccine (Razi, Iran), which had been prepared from a native strain, with the Nobilis ORT Inac (Intervet, The Netherlands) through a challenge trial.

Materials and Methods: Seventy-two 1-day-old specific pathogen-free White Leghorn chickens were used in this study. The birds were divided randomly into four groups. Following the vaccination and challenge of the birds, the efficacy of the Razi and the Intervet ORT vaccines was evaluated by serological, bacteriological, and molecular methods.

Results: The antibody titer in vaccinated groups was determined to be significantly higher than unvaccinated birds. In addition, the difference in postmortem lesion scores between the vaccinated and unvaccinated birds was significant. The differences in the means of the antibody titers and postmortem lesion scores in birds that were vaccinated by the Razi and Intervet ORT vaccines were not significant.

Conclusion: Considering the results of this study, it can be concluded that the Iranian native ORT vaccine was comparable to the Intervet vaccine. The Razi ORT vaccine has effectively decreased the duration of the ORT infection and can effectively protect the chickens against an ORT infection.
\end{abstract}

Keywords: challenge, chickens, efficacy, Ornithobacterium rhinotracheale, polymerase chain reaction, vaccine.

\section{Introduction}

Respiratory tract diseases are commonly encountered health problems in poultry operations. Ornithobacterium rhinotracheale (ORT) is a Gramnegative pathogen microorganism that causes respiratory tract diseases in chickens and is associated with retarded growth, decreased egg production, increased mortality, and, inevitably, economic losses in poultry $[1,2]$.

Unfortunately, most ORT strains are now resistant to most types of antibiotics $[3,4]$. Treatment of an ORT infection is really difficult and cannot be achieved effectively through antibiotic use. Probably, the best way to control ORT infections is by vaccination $[5,6]$. Although vaccination with an inactivated oil adjuvant vaccine was successful in reducing outbreaks of ORT [7], the major challenge in vaccine development against bacterial infections is the existence of different serotypes within a pathogen species [8]. The most challenging studies have concluded

Copyright: Ghasemipour, et al. Open Access. This article is distributed under the terms of the Creative Commons Attribution 4.0 International License (http://creativecommons.org/licenses/ by/4.0/), which permits unrestricted use, distribution, and reproduction in any medium, provided you give appropriate credit to the original author(s) and the source, provide a link to the Creative Commons license, and indicate if changes were made. The Creative Commons Public Domain Dedication waiver (http:// creativecommons.org/publicdomain/zero/1.0/) applies to the data made available in this article, unless otherwise stated. that experimental inoculation with ORT alone causes minimal pathogenic lesions in chickens. The severity of ORT lesions is enhanced when there is concurrent infection with respiratory viruses [9-11], so to more accurately evaluate the Razi vaccine; we designed the experimental challenge system with native ORT bacteria and the LaSota Newcastle disease virus (NDV).

The aim of our study was to compare the efficacy of the first Iranian native ORT vaccine with the conventional ORT vaccine through the challenge system.

\section{Materials and Methods}

\section{Ethical approval}

The samples were collected under the usual veterinary service work in Iran; no specific permission required for such type of study. The present work was performed according to the national standards of Iran.

\section{Chickens}

Seventy-two 1-day-old specific pathogen-free (SPF) White Leghorn chickens (Venky's Company, India) were used in this study. The birds were divided randomly into four groups (18 chicks per group). The birds were housed at the Poultry Research Unit of Razi Vaccine and Serum Research Institute in separate specific cages in isolation rooms. The chickens had free access to sterile water and disinfected food and were not administered any other vaccination or treatment during the experiment. The water was sterilized using 
an autoclave, and the food was disinfected in special containers using formaldehyde.

\section{Bacteria}

The isolate ORT R87-7/1387(JF 810491) was used. This strain (Serotype A) was stored at $-70^{\circ} \mathrm{C}$. The organism was retrieved from frozen suspension and cultured for $48 \mathrm{~h}$ at $37^{\circ} \mathrm{C}$ on Columbia agar (Oxoid Ltd., Basingstoke, UK), with 5\% sheep blood, in 5\% $\mathrm{CO}_{2}$ atmosphere. The colonies were then transferred into the brain heart infusion (Oxoid Ltd., Basingstoke, UK) for $24 \mathrm{~h}$, at $37^{\circ} \mathrm{C}$, with agitation. At that point, the bacterial challenge inoculums were prepared by washing cultured bacteria twice in phosphate-buffered saline, and a suspension containing $1 \times 10^{10}$ colony-forming units $(\mathrm{CFU})$ per $0.5 \mathrm{ml}$ was prepared.

\section{Experimental design}

At the age of 14 days old, the chickens of Group V1 were vaccinated by subcutaneous injection in the neck region with $0.3 \mathrm{ml}$ (containing approximately $1 \times 10^{10}$ cells) of inactivated oil adjuvant of the native ORT vaccine. That vaccine was produced with Serotype A of the ORT that was isolated during past respiratory disease outbreaks on poultry farms in various provinces of Iran. The birds of Group V2 were injected by the same method with $0.25 \mathrm{ml}$ (containing approximately $1 \times 10^{10}$ cells) of the Nobilis ORT inactivated vaccine (Intervet International B. V., Boxmeer, The Netherlands) containing inactivated ORT Serotype A bacteria in a mineral oil adjuvant. The birds of Groups $\mathrm{C}_{1}$ and $\mathrm{C}_{2}$ were injected by the same method with $0.3 \mathrm{ml}$ of the sterile physiological saline. At 42 days of age (at 4 weeks after vaccination), the birds of Group $\mathrm{V}_{1}, \mathrm{~V}_{2}$, and $\mathrm{C}_{1}$ were challenged with a $10^{6} \mathrm{EID}_{50}$ per dose of the LaSota NDV vaccine by the ocular route and $1 \times 10^{10} \mathrm{CFU} / 0.5 \mathrm{ml}$ of the ORT by the intratracheal route. Each bird in Group $\mathrm{C}_{2}$ was given one drop of sterile, distilled water by the intraocular route and $0.5 \mathrm{ml}$ of sterile, physiological saline by the intratracheal route.

\section{Sampling}

After the challenge, typical clinical signs affected chickens, including respiratory signs (rale and gasping), and ruffled feathers were observed. Blood samples were collected from the brachial vein of birds at 2 weeks of age before vaccination, at 6 weeks of age (before the challenge), and at days 2,4 , $6,8,10$, and 12 after challenge (AC). The serum samples were tested to evaluate the antibody titer against Ornithobacteriosis, using the commercial ELISA system. In addition, three chickens in each group were randomly killed at 2, 4, 6, 8, 10, and 12 days $\mathrm{AC}$ (DAC) by cervical dislocation. After a postmortem investigation of the chickens, the samples of the trachea, lungs, air sacs, liver, and spleen of those birds were aseptically collected immediately and examined by bacteriological and molecular methods.

\section{Postmortem investigation of symptoms}

Postmortem investigations were performed at 2 , $4,6,8,10$, and $12 \mathrm{DAC}$, and the lesions were scored as described by van Empel et al. [12]. Airsacculitis was scored for the thoracic and abdominal air sacs separately. The average lesion scores were given as a percentage of the maximum possible score.

\section{Bacteriological analysis}

For microbiological analysis, the samples of the lungs, trachea, air sacs, liver, and spleen were aseptically inoculated on blood agar supplemented with 5\% sheep blood, $5 \mu \mathrm{g} / \mathrm{ml}$ of gentamicin, and $5 \mu \mathrm{g} / \mathrm{ml}$ of polymyxin $\mathrm{B}$. The plates were incubated in $10 \% \mathrm{CO}_{2}$ atmosphere at $37^{\circ} \mathrm{C}$ for at least $48 \mathrm{~h}$. Then, the suspicious colonies were subcultured, and the identities confirmed biochemically as previously described by van Empel et al. [13].

\section{Antibody detection}

Serum samples were tested for the presence of the ORT antibody using the BioChek ORT Antibody Test Kit (The Netherlands) by following the manufacturer's instructions.

\section{DNA extraction}

The suspension of tissue samples and the ORT cultured broth was used for DNA extraction; $0.5 \mathrm{ml}$ of the suspension of tissue samples or the ORT cultured broth was transferred into Eppendorf tubes. The tubes were centrifuged at 13,000 rpm for $15 \mathrm{~min}$; then, the sediments were transferred into new Eppendorf tubes and $100 \mu 1$ of lysis buffer $(20 \mathrm{mM}$ Tris-pH $8.0+150 \mathrm{mM}$ $\mathrm{NaCl}+10 \mathrm{mM}$ EDTA $+0.2 \%$ SDS) were added to each tube. Following a 4-h incubation at $56^{\circ} \mathrm{C}$, an equal volume of saturated phenol was added to the tubes and then centrifuged at 13,000 rpm for $15 \mathrm{~min}$. The upper phase was transferred into a new Eppendorf tube. An equal volume of phenol and chloroform was added to the tube and then centrifuged at $13,000 \mathrm{rpm}$ for $15 \mathrm{~min}$. The supernatant was separated carefully, and then, an equal volume of phenol was added and centrifuged at 13,000 rpm for $15 \mathrm{~min}$. The upper phase was transferred into a new tube. Subsequently, genomic DNA was precipitated with absolute ethanol and $0.3 \mathrm{M}$ sodium acetate at $-20^{\circ} \mathrm{C}$ for $20 \mathrm{~min}$. The mixture was then centrifuged at $13,000 \mathrm{rpm}$ for $10 \mathrm{~min}$, and the upper phase was discarded. The pellet was washed twice with $250 \mu 10$ f $90 \%$ and $70 \%$ ethanol, respectively, and each step was followed by 5 min of centrifugation. The pellet was dried and resuspended in $50 \mu \mathrm{l}$ sterile, distilled water and used as a target DNA in polymerase chain reaction (PCR).

\section{Primers}

The primers used in this study were designed by van Empel et al. [13]. The sequence of the primer pairs was as follows: OR 16S$\mathrm{F}_{1}$ (5'-GAGAATTAATTTACGGATTAAG-3') and OR 16S-R ${ }_{1}$ (5'-TTCGCTTGGTCTCCGAAGAT-3'). These primers amplify a $784 \mathrm{bp}$ fragment on the $16 \mathrm{~S}$ rRNA gene of ORT. 
PCR

The PCR was performed in a master cycler gradient thermocycler (Eppendorf, Hamburg, Germany) in a total reaction volume of $25 \mu \mathrm{l}$ containing $1 \mu \mathrm{l}$ of DNA template sample, $1 \mu \mathrm{l}$ of each primer $(10 \mathrm{pmol})$, $1 \mu 1$ deoxynucleotide triphosphates $\operatorname{mix}(10 \mathrm{mM})$, $1 \mu \mathrm{MgCl}_{2}$ (25 mM), $2.50 \mu \mathrm{l}$ PCR buffer (10X), and $0.25 \mu \mathrm{l}$ Taq DNA polymerase (1.25 units). All reagents were purchased from SinaClon Bioscience Co., Tehran, Iran. Amplification was obtained with an initial denaturation step at $94^{\circ} \mathrm{C}$ for $5 \mathrm{~min}$, followed by 30 cycles at $94^{\circ} \mathrm{C}$ for $1 \mathrm{~min}$ (denaturation), $54^{\circ} \mathrm{C}$ for $1 \mathrm{~min}$ (annealing), and $72^{\circ} \mathrm{C}$ for $2 \mathrm{~min}$. The final extension cycle was at $72^{\circ} \mathrm{C}$ for $10 \mathrm{~min}$. Then, $10 \mu \mathrm{l}$ of PCR products were separated by electrophoresis (100 volts for $1 \mathrm{~h}$ ) in $1 \%$ agarose gel (CinnaGen Co., Tehran, Iran) stained with $0.50 \mu \mathrm{g} / \mathrm{ml}$ safe stain. DNA fragments were visualized by Ultraviolet Transillumination (UVitec, Cambridge, UK) and compared with a $100 \mathrm{bp}$ DNA ladder. The isolate ORT R87-31/1387(JF 810491) and distilled water were used as the positive and negative controls.

\section{Statistical analysis}

The results were analyzed statistically using the SPSS software (version 22.0; SPSS Inc., Chicago, USA). The comparison of the means of ORT ELISA titers between and within groups was performed through ANOVA analysis, and the Duncan method was used for the cooperation of mean ORT ELISA titers of groups AC. Postmortem lesion scores in experimental groups were analyzed using a Chi-square analysis. In all tests, results with $\mathrm{p}<0.05$ were regarded as statistically significant.

\section{Results}

\section{Clinical findings}

None of the chickens died during the experiment. However, respiratory signs, including rale and gasping, were not detected at 2, 4, 6, 8, 10, and 12 $\mathrm{DAC}$ in chickens in the vaccinated groups. Clinical signs (rale, gasping, and ruffled feathers) were seen in birds of the positive control group, starting from 2 DAC, gradually increasing until 8 DAC, and lasting for $12 \mathrm{DAC}$. In birds in the vaccinated groups, the ruffled feathers were detected at 2 and 4 DAC, then this declined and was absent at 6 DAC. None of the clinical findings were detected in birds of the negative control group in DAC.

\section{Postmortem examination}

The results of postmortem lesion scores and the percentage of the maximum possible score of thoracic airsacculitis, abdominal airsacculitis, and pneumonia are presented in Table-1. No macroscopic lesions were observed in air sacs and lungs in the negative control group, which was not vaccinated with any of the vaccines and was not challenged with ORT, whereas the lesion scores were at a maximum in the challenge control group. The lesion scores on airsacculitis and pneumonia were at a minimum in the vaccinated groups. The comparison of the difference in lesion scores was between vaccinated groups $\left(\mathrm{V}_{1} \mathrm{vs}\right.$. $\left.\mathrm{V}_{2}\right)$, so between the vaccinated groups with the negative control group $\left(\mathrm{V}_{1}\right.$ and $\mathrm{V}_{2}$ vs. $\mathrm{C}_{2}$ ) were not significant (Table-2).

\section{Serology}

The antibody titer in different phases of the study is presented in Table-3. Before vaccination, the antibody to ORT was negative in all of the experimental groups. The vaccinated birds had a higher antibody titer when compared with unvaccinated groups and were significantly different, but the difference between vaccinated groups was not significant (Table-4). The mean antibody titer in vaccinated groups rose after the challenge with ORT, but no significant difference was

Table-1: Postmortem lesion scores in the experimental groups after challenge with the ORT.

\begin{tabular}{|c|c|c|c|c|c|c|c|c|c|c|c|c|c|c|c|}
\hline \multirow[t]{2}{*}{ Groups } & \multicolumn{5}{|c|}{ Thoracic air sacs } & \multicolumn{5}{|c|}{ Abdominal air sacs } & \multicolumn{5}{|c|}{ Lungs } \\
\hline & NO & $\begin{array}{c}\text { Score } \\
0\end{array}$ & $\begin{array}{c}\text { Score } \\
1\end{array}$ & $\begin{array}{c}\text { Score } \\
2\end{array}$ & $\begin{array}{c}\% \\
\text { MPS }\end{array}$ & NO & $\begin{array}{c}\text { Score } \\
0\end{array}$ & $\begin{array}{c}\text { Score } \\
1\end{array}$ & $\begin{array}{c}\text { Score } \\
2 \\
\end{array}$ & $\begin{array}{c}\% \\
\text { MPS }\end{array}$ & NO & $\begin{array}{c}\text { Score } \\
0\end{array}$ & $\begin{array}{c}\text { Score } \\
1 \\
\end{array}$ & $\begin{array}{c}\text { Score } \\
2 \\
\end{array}$ & $\begin{array}{c}\% \\
\text { MPS } \\
\end{array}$ \\
\hline$V_{1}$ & 18 & 15 & 3 & 0 & 8.3 & 18 & 16 & 2 & 0 & 2.8 & 18 & 16 & 2 & 0 & 5.6 \\
\hline$v_{2}^{1}$ & 18 & 16 & 2 & 0 & 5.6 & 18 & 18 & 0 & 0 & 0 & 18 & 17 & 1 & 0 & 2.8 \\
\hline$C_{1}^{2}$ & 18 & 3 & 2 & 13 & 77.8 & 18 & 4 & 1 & 13 & 75 & 18 & 8 & 3 & 7 & 42.7 \\
\hline$C_{2}^{1}$ & 18 & 18 & 0 & 0 & 0 & 18 & 18 & 0 & 0 & 0 & 18 & 18 & 0 & 0 & 0 \\
\hline
\end{tabular}

MPS = Maximum possible score, $\mathrm{NO}=$ Number of birds, $\mathrm{V}_{1}=$ Razi ORT vaccine, $\mathrm{V}_{2}=$ Intervet $\mathrm{ORT}$ vaccine, $\mathrm{C}_{1}=$ Positive control, $\mathrm{C}_{2}=$ Negative control

Table-2: Comparison of the postmortem lesions between experimental groups after challenge with the ORT.

\begin{tabular}{lccc}
\hline Comparison of groups & & Postmortem lesions \\
\cline { 2 - 4 } & Thoracic air sacs & Abdominal air sacs & Lungs \\
\hline$V_{1}$ versus $V_{2}$ & $0.232^{\text {ns }}$ & $1.029^{\text {ns }}$ & $0.364^{\text {ns }}$ \\
$V_{1}$ versus $C_{1}$ & $21.200^{* *}$ & $21.048^{* *}$ & $9.967^{* *}$ \\
$V_{1}$ versus $C_{2}$ & $3.273^{\text {ns }}$ & $1.029^{\text {ns }}$ & $2.118^{\text {ns }}$ \\
$V_{2}$ versus $C_{1}$ & $21.895^{* *}$ & $22.909^{* *}$ & $11.240^{* *}$ \\
$V_{2}$ versus $C_{2}$ & $2.118^{\text {ns }}$ & $0.000^{\text {ns }}$ & $1.029^{\text {ns }}$ \\
$C_{1}$ versus $C_{2}$ & $25.714^{* *}$ & $22.909^{* *}$ & $13.846^{* *}$ \\
\hline
\end{tabular}

ns $=$ Not significant, $* *=$ Significant $p<0.01 . V_{1}=$ Razi ORT vaccine, $V_{2}=$ Intervet ORT vaccine, $C_{1}=$ Positive control, $\mathrm{C}_{2}=$ Negative control 
Table-3: Mean ORT ELISA titer in different phases of study.

\begin{tabular}{lccc}
\hline Group & \multicolumn{3}{c}{ Phases } \\
\cline { 2 - 4 } & BV & BC & AC \\
\hline $\mathrm{V}_{1}$ & $0.00 \pm 0.00$ & $12416.6 \pm 1971.6$ & $14184.6 \pm 1567.81$ \\
$\mathrm{~V}_{2}$ & $0.00 \pm 0.00$ & $14660.5 \pm 1239.4$ & $16079.5 \pm 1175.83$ \\
$\mathrm{C}_{1}$ & $0.00 \pm 0.00$ & $0.00 \pm 0.00$ & $9481.60 \pm 449.89$ \\
$\mathrm{C}_{2}$ & $0.00 \pm 0.00$ & $0.00 \pm 0.00$ & $0.00 \pm 0.00$ \\
\hline
\end{tabular}

$\mathrm{BV}=$ Before vaccination, $\mathrm{BC}=$ Before challenge, $\mathrm{AC}=$ After challenge, $\mathrm{V}_{1}=$ Razi ORT vaccine, $\mathrm{V}_{2}$ =Intervet ORT vaccine, $\mathrm{C}_{1}=$ Positive control, $\mathrm{C}_{2}=$ Negative control

Table-4: Variance analysis for ORT ELISA titer after challenge (AC).

\begin{tabular}{lcccc}
\hline S.o.v. & df & Mean square & F & Sig. \\
\hline Between groups & 3 & 33283.844 & 185.749 & 0.000 \\
Within groups & 36 & 179.187 & & \\
CV\% & & $15.68 \%$ & & \\
\hline
\end{tabular}

Sig.=Significance

Table-5: Comparison of mean ORT ELISA titer within the vaccinated groups before and after challenge with the ORT.

\begin{tabular}{lllc}
\hline Group & t-value & df & Significance \\
\hline$V_{1}$ & $-0.702^{\text {ns }}$ & 18 & 0.492 \\
$V_{2}$ & $-0.831^{\text {ns }}$ & 18 & 0.417 \\
\hline
\end{tabular}

ns $=$ Non-significance, $V_{1}=$ Razi ORT vaccine, $V_{2}=$ Intervet ORT vaccine

found within vaccinated groups before and after the challenge (Table-5).

\section{Bacteriology}

The results of bacteriological isolation are displayed in Table-6. ORT was never isolated from the spleen and liver of the chickens at 2, 4, 6, 8, 10, and $12 \mathrm{DAC}$ in all of the experimental groups. Like in the vaccinated groups, ORT was not recovered from the lungs, trachea, and air sacs of the birds. In the positive control group, ORT was isolated at 2 and 4 DAC from the trachea and air sacs of the birds. ORT was only found at 4 DAC from the lungs of the chickens in the positive control group. In the negative control group, ORT was not found in DAC.

\section{Molecular analysis}

After the challenge, the molecular analysis (PCR) was performed on different parts of the respiratory system (lungs, trachea, and air sacs) and visceral organs (spleen and liver) of the chickens. Finally, ORT was only detected from samples of the lungs, trachea, and air sacs of birds at 2 DAC in the vaccinated groups. In the positive control group, ORT was detected from the lungs, trachea, and air sacs at 2 and 4 DAC. In the negative control group, ORT was not detected in DAC (Table-7).

\section{Discussion}

An ORT infection is considered of the emerging diseases of poultry. Various studies on the control of an ORT infection in poultry through vaccination have been described $[7,8]$. The vaccination of chickens was effective and protected from pathologic changes [1]. The major challenge in vaccine development against bacterial infections is the existence of different serotypes within a pathogen species [8]. Since Serotype A of ORT is the most prevalent serotype in chickens [1], this serotype chooses to produce the inactivated vaccine. The Razi ORT vaccine had been prepared from the native strain. This native strain (Serotype A) was isolated during past respiratory disease outbreaks on poultry farms in various provinces of Iran.

In the present challenge trial, no mortality was observed in chickens. The severity of clinical signs, the duration of the disease, and the mortality of ORT outbreaks are extremely variable depending on the strains of bacteria and the breed of the chickens [1]. The clinical signs of birds in this study are similar to, but generally milder than, those seen in filed cases. This difference may be attributed to the often inadequate environmental and management conditions (high animal density, inadequate ventilation, and high ammonia levels) and additional pathogens encountered in the field, exacerbating any disease that has been brought about. The birds used in this study were SPF and kept in spacious rooms with high-efficiency particulate air-filtered air with no extraneous pathogens interplaying.

Based on the results of the postmortem examination, the airsacculitis and pneumonia were most severe in chickens of the positive control group, whereas the airsacculitis and pneumonia were at a minimum in the experimental groups vaccinated with the Razi and the Intervet vaccines. Results of this study show that in vaccinated groups, gross lesions occurred less frequently than in unvaccinated birds, and vaccinating chickens had a striking effect on airsacculitis and pneumonia, in agreement with the findings of Murthy et al. [14] and Sprenger et al. [15]. Significant differences in lesion scores were seen between the vaccinated groups and the unvaccinated birds that were challenged with ORT and ND. A significant difference in lesion scores was not seen between the birds that were vaccinated with the Razi ORT vaccine and the birds that were vaccinated with the Intervet vaccine (Table-2). After the challenge in the vaccinated groups, a significant reduction in pathology was observed, although the organ lesions were not reduced to zero. Our results were in agreement with the study of Hegazy et al. [16].

The titer of antibody to ORT in the blood sera of vaccinated birds was determined to be significantly higher than that of unvaccinated chickens(Figure-1). In the present study, before vaccination, antibodies to ORT were negative in all of the experimental groups, but the chickens that received vaccines had a higher antibody titer when compared with the negative control group and were significantly different. Our findings of the effective role of the vaccine to evoke high antibody titers against ORT were correlated with the 
Table-6: Results of the culture of the samples after challenge with the ORT.

\begin{tabular}{|c|c|c|c|c|c|c|c|c|c|c|c|c|c|c|c|c|c|c|c|c|c|c|c|c|}
\hline \multirow[t]{2}{*}{ Organs } & \multicolumn{4}{|c|}{ Days (AC) 2} & \multicolumn{4}{|c|}{ Days (AC) 4} & \multicolumn{4}{|c|}{ Days (AC) 6} & \multicolumn{4}{|c|}{ Days (AC) 8} & \multicolumn{4}{|c|}{ Days (AC) 10} & \multicolumn{4}{|c|}{ Days (AC) 12} \\
\hline & $v_{1}$ & $v_{2}$ & $\mathrm{C}_{1}$ & $\mathrm{C}_{2}$ & $v_{1}$ & $\mathbf{v}_{2}$ & $C_{1}$ & $\mathrm{C}_{2}$ & $v_{1}$ & $\mathbf{v}_{2}$ & $C_{1}$ & $\mathrm{C}_{2}$ & $v_{1}$ & $\mathbf{v}_{2}$ & $\mathrm{C}_{1}$ & $\mathrm{C}_{2}$ & $v_{1}$ & $v_{2}$ & $C_{1}$ & $C_{2}$ & $v_{1}$ & $v_{2}$ & $C_{1}$ & $C_{2}$ \\
\hline rachea & - & - & + & - & - & - & + & - & - & - & - & - & - & - & - & - & - & - & - & - & - & - & - & - \\
\hline Lungs & - & - & - & - & - & - & + & - & - & - & - & - & - & - & - & - & - & - & - & - & - & - & - & - \\
\hline Airsacs & - & - & + & - & - & - & + & - & - & - & - & - & - & - & - & - & - & - & - & - & - & - & - & - \\
\hline Liver & - & - & - & - & - & - & - & - & - & - & - & - & - & - & - & - & - & - & - & - & - & - & - & - \\
\hline Spleen & - & - & - & - & - & - & - & - & - & - & - & - & - & - & - & - & - & - & - & - & - & - & - & - \\
\hline
\end{tabular}

$\mathrm{AC}=$ After challenge, $\mathrm{V}_{1}=$ Razi ORT vaccine, $\mathrm{V}_{2}=$ Intervet ORT vaccine, $\mathrm{C}_{1}=$ Positive control, $\mathrm{C}_{2}=$ Negative control

Table-7: Results of the PCR of the samples after challenge with the ORT.

\begin{tabular}{|c|c|c|c|c|c|c|c|c|c|c|c|c|c|c|c|c|c|c|c|c|c|c|c|c|}
\hline \multirow[t]{2}{*}{ Organs } & \multicolumn{4}{|c|}{ Days (AC) 2} & \multicolumn{4}{|c|}{ Days (AC) 4} & \multicolumn{4}{|c|}{ Days (AC) 6} & \multicolumn{4}{|c|}{ Days (AC) 8} & \multicolumn{4}{|c|}{ Days (AC) 10} & \multicolumn{4}{|c|}{ Days (AC) 12} \\
\hline & $\mathbf{v}_{1}$ & $\mathbf{V}_{2}$ & $\mathrm{C}_{1}$ & $\mathrm{C}_{2}$ & $\mathbf{v}_{1}$ & $\mathbf{V}_{2}$ & $\mathrm{C}_{1}$ & $\mathrm{C}_{2}$ & $\mathbf{v}_{1}$ & $\mathbf{v}_{2}$ & $\mathrm{C}_{1}$ & $\mathrm{C}_{2}$ & $\mathbf{V}_{1}$ & $\mathbf{v}_{2}$ & $\mathrm{C}_{1}$ & $\mathrm{C}_{2}$ & $\mathbf{v}_{1}$ & $\mathbf{v}_{2}$ & $\mathrm{C}_{1}$ & $\mathrm{C}_{2}$ & $\mathbf{v}_{1}$ & $\mathbf{V}_{2}$ & $\mathrm{C}_{1}$ & $\mathrm{C}_{2}$ \\
\hline Trachea & + & + & + & - & - & - & + & - & - & - & - & - & - & - & - & - & - & - & - & - & - & - & - & - \\
\hline Lungs & + & + & + & - & - & - & + & - & - & - & - & - & - & - & - & - & - & - & - & - & - & - & - & - \\
\hline Airsacs & + & + & + & - & - & - & + & - & - & - & - & - & - & - & - & - & - & - & - & - & - & - & - & - \\
\hline Liver & - & - & - & - & - & - & - & - & - & - & - & - & - & - & - & - & - & - & - & - & - & - & - & - \\
\hline Spleen & - & - & - & - & - & - & - & - & - & - & - & - & - & - & - & - & - & - & - & - & - & - & - & - \\
\hline
\end{tabular}

$\mathrm{AC}=$ After challenge, $\mathrm{V}_{1}=$ Razi ORT vaccine, $\mathrm{V}_{2}=$ Intervet ORT vaccine, $\mathrm{C}_{1}=$ Positive control, $\mathrm{C}_{2}=$ Negative control

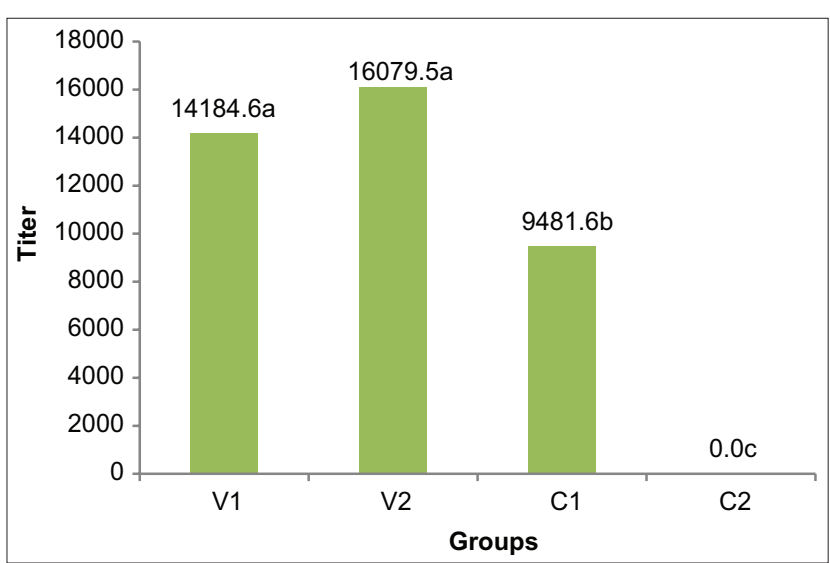

Figure 1: Mean comparison of ORT ELISA titer in experimental groups after challenge with the ORT $\mathrm{V}_{1}$, Razi ORT vaccine; $\mathrm{V}_{2}$, Intervet ORT vaccine; $\mathrm{C}_{1}$, positive control; $\mathrm{C}_{2}$, negative control

reports of Cauwerts et al. [6], Schuijffel et al. [5], and Erganis et al. [7]. After vaccination and after the challenge, no significant difference was observed between the titer of antibody to the ORT in the blood sera of vaccinated groups.

After the challenge, bacteriological (culture) and molecular (PCR) analyses were performed on the samples of the respiratory organs (lungs, air sacs, and trachea) and visceral organs (liver and spleen). In all of the experimental groups, ORT was not detected by the culture and PCR methods from the visceral organ samples taken in the DAC. This is in agreement with the study of Hegazy et al. [16] and Umali et al. [4]. The bacterium primarily infects the trachea, lungs, and air sacs, but can also manifest as a systemic disease $[8,12]$. The ORT bacterium is most commonly isolated from the trachea and lungs of naturally or experimentally infected birds [17-19]. In our study, the bacterium was not isolated from the respiratory system by the culture in the vaccinated groups in the DAC. In vaccinated groups, ORT was detected by the PCR at 2 DAC, but in the positive control group, the ORT was isolated by the culture and PCR from the respiratory organs until 4 DAC. Like in the vaccinated groups, the bacterium was only detected in PCR from samples of the lungs, trachea, and air sacs at 2 DAC. ORT can normally isolate only at an early stage of the infection and attempts to recover it at a later stage often fail [1]. The use of PCR enables the attainment of positive results in samples from the later days after infection, which remained negative in bacteriological analyses. The PCR technique additionally detected the bacterial genetic material in respiratory organs at 4 DAC in unvaccinated groups. The OR16S-F1 and OR16S-R1 primers combination used in our study were very specific in amplifying a $784 \mathrm{bp}$ fragment of the 16S rRNA gene of ORT [20].

\section{Conclusion}

Considering the results of the clinical signs, postmortem lesions, serology, culture, and PCR in this study, it can be concluded that no significant difference was found been between the Razi ORT vaccine and the Intervet ORT vaccine. The vaccination of the birds by the Iranian native ORT vaccine has effectively decreased the duration of the ORT infection and can effectively protect the chickens against an ORT infection.

\section{Authors' Contributions}

$\mathrm{KA}, \mathrm{MB}$, and $\mathrm{HG}$ designed and performed the study. MB and $\mathrm{HG}$ participated in challenging, collecting data. KA, MB, and $\mathrm{HG}$ participated in the interpretation of data. NG collected samples, participated in bacteria isolation, performed PCR, analysis of data, and draft of the manuscript. KA wrote and revised the manuscript. All authors read and approved the final manuscript. 


\section{Acknowledgments}

The authors would like to thank the Razi Vaccine and Serum Research Institute of Karaj, Agricultural Research, Education and Extension Organization for providing facilities and financial support. The investigators would like to thank Dr. A. Nouri for his assistance in vaccination, collecting the samples, and cooperation in the laboratory work. This work has been supported by the Razi Vaccine and Serum Research Institute, Karaj, Iran (No: 12-18-18-9460-94001).

\section{Competing Interests}

The authors declare that they have no competing interests.

\section{Publisher's Note}

Veterinary World remains neutral with regard to jurisdictional claims in published institutional affiliation.

\section{References}

1. Chin, R.P., Van Empel, P.C.M. and Hafez, H.M. (2013) Ornithobacterium rhinotracheale infection. In: Swayne, E.D., editor. Diseases of Poultry. $13^{\text {th }}$ ed. Blackwell Publishing Ltd., United Kingdom, p859-873.

2. Thieme, S., Mühldorfer, K., Lüschow, D. and Hafez, H.M. (2016) Molecular characterization of the recently emerged poultry pathogen Ornithobacterium rhinotracheale by multilocus sequence typing. PLoS One, 11(2): e0148158.

3. Watteyn, A., Devreese, M., Plessers, E., Wyns, H., Garmyn, A., Reddy, V.R., Pasmans, F., Martel, A., Haesebrouck, F. and De Backer, P. (2016) Efficacy of gamithromycin against Ornithobacterium rhinotracheale in Turkey poults pre-infected with Avian metapneumovirus. Avian Pathol., 45(5): 545-551.

4. Umali, D., Shirota, K., Sasai, K. and Katoh, H. (2017) Characterization of Ornithobacterium rhinotracheale from commercial layer chickens in Eastern Japan. Poult. Sci., 97(1): 24-29.

5. Schuijffel, D.F., Van Empel, P.C., Segers, R.P, Van Putten, J.P. and Nuijten, P.J. (2006) Vaccine potential of recombinant Ornithobacterium rhinotracheale antigens. Vaccine, 24(11): 1858-1867.

6. Cauwerts, K., Herdt, P.D., Haesebrouck, F., Vervloesem, J. and Ducatelle, R. (2002) The effect of Ornithobacterium rhinotracheale vaccination of broiler breeder chickens on the performance of their progeny. Avian Pathol., 31(6): 619-624.

7. Erganis, O., Hadimli, H., Kav, K., Sayin, Z. and Aras, Z. (2010) Production and development of vaccines for Ornithobacterium rhinotracheale infection in Turkeys. Eurasian J. Vet. Sci., 26(2): 101-107.

8. Schuijffel, D.F., Van Empel, P.C., Pennings, A.M., Van Putten, J.P. and Nuijten, P.J. (2005) Successful selection of cross-protective vaccine candidates for Ornithobacterium rhinotracheale infection. Infect. Immun., 73(10): 6812-6821.

9. Marien, M., Decostere, A., Martel, A., Chiers, K., Froyman, R. and Nauwynck, H. (2005) Synergy between avian pneumovirus and Ornithobacterium rhinotracheale in Turkeys. Avian Pathol., 34(3): 204-211.

10. Eroksuz, H., Ozbey, G., Cevik, A., Tarakci, B.G. and Balik, D.T. (2006) Immuno-histochemical, pathological, enzyme-linked immunosorbent assay and polymerase chain reaction analysis of experimental Ornithobacterium rhinotracheale infection in quails (Coturnix coturnix japonica). Rec. Med. Vet., 157(4): 197-202.

11. Ellakany, H., Elbestawy, A., Abd-Elhamid, H., Gado, A., Nassar, A., Abdel-Latif, M., Ghanima, I.A., Abd El-Hack, M., Swelum, A. and Saadeldin, I. (2019) Effect of experimental Ornithobacterium rhinotracheale infection along with live infectious bronchitis vaccination in broiler chickens. Poult. Sci., 98(1): 105-111.

12. van Empel, P., van den Bosch, H., Goovaerts, D. and Storm, P. (1996) Experimental infection in Turkeys and chickens with Ornithobacterium rhinotracheale. Avian Dis., 40(4): 858-864.

13. van Empel, P., Vrijenhoek, M., Goovaerts, D. and van den Bosch, H. (1999) Immunohistochemical and serological investigation of experimental Ornithobacterium rhinotracheale infection in chickens. Avian Pathol., 28(2): 187-193.

14. Murthy, T.R., Dorairajan, N., Balasubramaniam, G., Dinakaran, A.M. and Kalaimathi, R. (2007) The effect of vaccination of pullets against Ornithobacterium rhinotracheale infection. Avian Pathol., 36(6): 481-485.

15. Sprenger, S.J., Halvorson, D.A., Nagaraja, K.V., Spasojevic, R., Dutton, R.S. and Shaw, D.P. (2000) Ornithobacterium rhinotracheale infection in commercial laying-type chickens. Avian Dis., 44(3): 725-729.

16. Hegazy, A.M., Hassanin, O. and Ismaeil, G.F. (2015) An experimental co-infection of broilers with local isolates of Ornithobacterium rhinotracheale and Escherichia coli. Zag. Vet. J., 43(3): 82-94.

17. De la Rosa-Ramos, M.A., Muñoz-Solís, K., PalmaZepeda, M., Gutierrez-Castillo, A.C., López Villegas, E.O., Guerra-Infante, F.M. and Castro-Escarpulli, G. (2018) Adherence of Ornithobacterium rhinotracheale to chicken embryo lung cells as a pathogenic mechanism. Avian Pathol., 47(2): 172-178.

18. Gavrilović, P., Gavrilović, A., Vidanović, D., Parunović, J. and Jovanović, M. (2016) Comparative pathomorphological, bacteriological and serological examination of broiler breeders and pheasants experimentally infected with Ornithobacterium rhinotracheale. Avian Pathol., 45(5): 513-519.

19. Hauck, R., Chin, R.P. and Shivaprasad, H. (2015) Retrospective study on the isolation of Ornithobacterium rhinotracheale from chickens and Turkeys in Central California: 294 cases (2000-12). Avian Dis., 59(1): 130-137.

20. De Oca-Jimenez, R.M., Vega-Sanchez, V., MoralesErasto, V., Salgado-Miranda, C., Blackall, P.J. and Soriano-Vargas, E. (2018) Phylogenetic relationship of Ornithobacterium rhinotracheale strains. J. Vet. Med. Sci., 80(6): 869-873. 